\title{
ŁUKASZ TISCHNER
}

(iD) https://orcid.org/0000-0001-8640-9648

Uniwersytet Jagielloński

lukasz.tischner@uj.edu.pl

\section{PRZEKŁAD JAKO PRÓBA „PRZYŚWIADCZENIA". WOKÓŁ WIERSZA STANISŁAWA BARAŃCZAKA PIĘĆ POCZTÓWEK OD I DO EMILY DICKINSON}

\section{Abstract \\ Translation as a Test of Assent: Stanisław Barańczak's Poem Five Postcards from and to Emily Dickinson}

Stanisław Barańczak is well known not only as a poet, but also as an extremely prolific translator who became famous for translating the works of Shakespeare and British and American poets. In the 1980s, just before and immediately after his forced political emigration to the United States, he extensively translated religious poets (e.g. 'metaphysical poets', Gerard Manley Hopkins, Emily Dickinson). This was a rather surprising choice, given the fact that Barańczak was an agnostic, distrustful of the world of religion. On the other hand, however, it was at that time that he introduced in his own poetry ("Atlantis", "A Postcard from this World") phrases testing the possibility of religious "real assent" (John Henry Newman's term). It seems that for Barańczak translation of some poets becomes not only an opportunity to broaden the scope of the Polish language and improve his own technique, but also an attempt to "assent" to the religious vision of the world, which is evoked by the lyric of the poets he admired. The poem Five Postcards from and to Emily Dickinson seems to support such an interpretation. My analyses are inspired by scholars of Barańczak's work, as well as by those who study literature and religion: Paul Ricœur and Charles Taylor.

Keywords: Stanisław Barańczak, Emily Dickinson, poetry translation, religion, assent

Słowa kluczowe: Stanisław Barańczak, Emily Dickinson, przekład poezji, religia, przyświadczenie 
W moim tekście stawiam sobie tyleż ambitne, co lekkomyślne zadanie złapania kilku srok za ogon. Chciałem napisać coś o tajnikach przekładu, o istocie poezji, związkach literatury i religii, a przede wszystkim o Stanisławie Barańczaku i jego niezwykłym wierszu, w którym podejmuje on rozmowę z Emily Dickinson. Jak wiadomo, każde z tych poszczególnych zagadnień to temat-rzeka, czy też, pozostając w kręgu skojarzeń myśliwskich, rzadki głuszec, do którego podchodzi się długo, bacznie i mozolnie. Spróbuję zaryzykować i nie wycofywać się ze swojego zamiaru, bo mam wrażenie, że w przypadku Pięciu pocztówek od i do Emily Dickinson konieczne jest choćby prowizoryczne uchwycenie związków między wierszem i tymi rozległymi kwestiami, którym poświęcono całe biblioteki. Być może ta wieloraka sieć potencjalnych zależności sprawia, że ów poetycki dialog nie był szerzej komentowany przez krytyków, choć dostrzegali oni jego wyjąątkowość ${ }^{1}$.

Podstawowym celem moich rozważań jest interpretacja poematu Barańczaka, więc w punkcie wyjścia zakładam, że to sam wiersz i konteksty, które uruchamia, naprowadzą mnie na trop ogólniejszych zagadnień i pozwolą zrozumieć, co w tym konkretnym utworze jawi się jako sens przekładu czy istota poezji.

Pięć pocztówek od i do Emily Dickinson to poemat napisany już w Stanach Zjednoczonych, który pochodzi z pierwszego emigracyjnego tomiku Barańczaka, jakim była wydana w roku 1986 Atlantyda. Dominującym tematem zbioru było doświadczenie wygnania/emigracji. Barańczak nie jest typowym egzulem - broni się przed goryczą wykorzenienia, w czym pomaga mu odkrycie (tyleż wyzwalające, co przytłaczające), że wygnanie, obumieranie światów, które pozostawiamy za sobą, wpisane jest w codzienność także nieemigracyjnej egzystencji. Tytułowy wiersz tomu Atlantyda jest sensualnie konkretnym wspomnieniem wizyty u poznańskiego fryzjera, który opowiadał przy strzyżeniu o poruczniku Woźniaku ,prostym jak świca"2. Podmiot wiersza notuje, że już wtedy zapadała się w oceanie niepamięci/nicości „Atlantyda porucznika Woźniaka (...), o którym niczego więcej się nie dowiem" (Barańczak 2013: 305). Nierozerwalnie związany $\mathrm{z}$ doświadczeniem emigracji jest przymus tłumaczenia, zawieszenia między

1 Por. np. uwagi zamieszczone w najwszechstronniejszym opracowaniu na temat poezji Barańczaka (Kandziora 2007: 325). Chyba tylko Magdalena Rabizo-Birek (Rabizo-Birek:1994) poświęciła temu utworowi osobny szkic. Nie podejmuje ona jednak kwestii, które staram się naświetlić w moim artykule.

${ }^{2}$ Wiersz ten ma w sobie coś z apokaliptycznej aury Fryzjerów Juliana Tuwima. 
językiem/światem własnym i obcym. Pisał o tym Jerzy Kandziora, który odnosząc się do amerykańskiego etapu życia poety, posłużył się uogólniającą metaforą: „Doświadczenie translacji w najszerszym, życiowym sensie stało się losem, podstawowym doświadczeniem egzystencjalnym Stanisława Barańczaka" (Kandziora 2007: 326).

Trzeba wreszcie powiedzieć o rzeczy oczywistej, czyli przypomnieć, że Stanisław Barańczak już (a może zwłaszcza) we wczesnym okresie emigracji namiętnie tłumaczył poezję. Na przełomie lat 70. i 80. zanurzony był w świecie angielskiej poezji metafizycznej XVII wieku i Gerarda Manleya Hopkinsa, a przekład liryku o incipicie Bywa światła pochylenie dołączonego do Atlantydy dowodzi, że w tamtym czasie zaczął fascynować się i spolszczać Emily Dickinson. O Barańczaku translatorze, który nie tylko oszołomił liczbą najbardziej wymagających przekładów, ale i tworzył własną teorię thumaczenia, napisano wiele rozpraw. Dla potrzeb mojego wywodu przytoczę jedynie opinie dwóch badaczek, które zajmowały się zależnościami między własną twórczością Barańczaka i tą, którą spolszczał. Ewa Rajewska zauważa, że Barańczak inspiruje się cudzymi utworami, a jego przekłady są dopełnieniem własnej poezji (Rajewska 2007). Natomiast Monika Kaczorowska stwierdza, że jego osobowość poetycka ,jest nadrzędną kategorią organizującą całość praktyki twórczej”, co sprawia, że translatolożka traktuje jego przekłady ,nie jako inspirację lub wprawkę do własnej twórczości, lecz jako własne utwory” (Kaczorowska 2011: 25-26). Nie zamierzam badać tłumaczeń poety pod kątem ich adekwatności wobec oryginału (jego propozycje bywają śmiałe, a czasem nadmiernie wyrafinowane, lecz trudno mu zarzucić ignorancję). Interesują mnie raczej przyczyny, dla których szuka u przekładanych poetów inspiracji, chce dzięki nim wzbogacić własną twórczość. Wiersz, którym chcę się zająć, nie pozwala rozstrzygnąć, która z dwu badaczek jest bliższa prawdy. Choćby dlatego, że nie jest on przekładem, ale pastiszem. Równocześnie jednak moje analizy pozwalają dostrzec pewien wymiar translatologii, który wymyka się starannym badaniom filologicznym. Wymiar ów, mający związek z tym, co w dalszej części wywodu nazwę za Paulem Ricœurem objawieniowym wymiarem poezji, wyczula na granice własnej osobowości poetyckiej Barańczaka, która - przynajmniej intencjonalnie - musi skapitulować przed dziełem, jakie próbuje oddać w przekładzie.

W tym miejscu trzeba przywołać koncepcję poezji Barańczaka, która krystalizowała się w latach 80., gdy znalazł się na emigracji i szukał pomocy u autorów, których tłumaczył. Najpełniej wyraził ją w dwóch manifestach: 
Zemsta ręki śmiertelnej i Tablica z Macondo. Już w tym pierwszym, o tytule zapożyczonym od Szymborskiej, wypowiada sądy, które mogą się kojarzyć z tradycją niemieckiego romantyzmu i Ricœurowskiej hermeneutyki. To dość zaskakujące, bo Barańczak-teoretyk wychował się na strukturalizmie i krytycznie oceniał koncepcje języka, które mówiły o jego tajemniczości. A jednak w Zemście ręki śmiertelnej czytamy:

Tym, co różni poezję od jakiegokolwiek innego słownego opisu świata, jest zawarta w wierszu (ma się rozumieć, tylko w naprawdę dobrym wierszu) jego narzucająca się nieprzypadkowość, „tak-a-nie-inność”, wewnętrzna konieczność (...) Wiemy, że wszystko, co istnieje, zginie: a przecież wiersz potrafi żyć bez końca. Wiemy, że światem rządzi przypadek i chaos: a przecież wiersz oświadcza nam, że nie ma w nim nic przypadkowego (Barańczak 1996b: 129-130).

W Tablicy z Macondo dopowiadał coś równie fundamentalnego. Swoją „poetykę normatywną” streszczał w krótkim komunikacie o brzmieniu: „ON JEST". Jak to rozumieć? Oddajmy mu znów głos:

Naczelna zasada poezji, cała ta paradoksalna zwięzłość produkująca wieloznaczność i wieloznaczność istniejąca na przekór zwięzłości, jest nie tylko środkiem samoobrony jednostki $\mathrm{w}$ zmaganiach z Nicością. Jest również poświadczeniem istnienia trzech zewnętrznych instancji, które to mają ze sobą wspólnego, że w walce z Nicością każda jest sprzymierzeńcem jednostki, a zarazem ją przerasta. Te trzy obiekty odniesienia to Inni, Świat i Transcendencja. (...) Poezja mówi (...) o Innych, Świecie i Transcendencji, ale jest także dialogiem z nimi. Jest skierowana do nich. (...) Nad każdym wierszem zawisa uważne oko Czytelnika (choćby tylko wyobrażonego), Rzeczywistości obiektywnej (choćby rację miał biskup Berkeley) i Absolutnego Punktu Odniesienia (choćby był tylko hipostazą, która powstrzymuje nas od rozpadu) (Barańczak 1996 a: 168-169).

Sceptycyzm wyrażony w nawiasowych dopowiedzeniach ujawnia, że Barańczak należy do „epoki świeckiej”3, w której metafizyczny realizm i Absolutny Punkt Odniesienia utraciły czar oczywistości.

3 Termin ten przejmuję od Charlesa Taylora, który upowszechnił go w swej monumentalnej monografii A Secular Age. W jego ujęciu wyróżnikiem ,epoki świeckiej”, czyli z grubsza rzecz biorąc okresu zainaugurowanego w XX wieku i trwającego do dzisiaj, jest opcjonalność stanowisk teistycznych. Nie ma on zatem na myśli obumierania religii, ale zmianę warunków wiary, która przestała być samooczywistym aksjomatem i musi się konfrontować ze stanowiskami ateistycznymi. Więcej piszę na ten temat w artykule o wkładzie Charlesa Taylora do badań nad literaturą i religią (Tischner 2020: 19-55). 
By lepiej zrozumieć poglądy Barańczaka na temat poezji, przytoczmy jeszcze jego autokomentarz do Tablicy z Macondo, w którym tłumaczył, że zdanie „ON JEST”: „to (...) «wyznanie wiary», nie tyle wiary w sensie ściśle religijnym, ile raczej wiary w realność bytu rzeczy wobec nas zewnętrznych i w zasadniczą Sensowność tego, co istnieje" (Barańczak 1993: 78).

Przywołane powyżej deklaracje wskazują na zaskakujący wymiar poezji, który za Ricœurem można nazwać „drugorzędną funkcją referencyjną” (Ricœur 2011: 67). Polega ona na tym, że język poetycki odnosi się do „naszych rozlicznych sposobów przynależenia do świata, zanim przeciwstawimy nam samym rzeczy jako «przedmioty», zwrócone ku jakiemuś «podmiotowi»» (Ricœur 2011: 67). Ricœur przekonuje, że ta specyficzna referencyjna funkcja dyskursu poetyckiego kryje w sobie ,wymiar objawienia”, objawienia rozumianego w sensie elementarnym, przedreligijnym, nie chodzi bowiem o jakąś prawdę teologiczną czy biblijną, ale o odkrywanie naszego pierwotnego zakorzenienia w świecie. To źródłowe zakorzenienie przesłaniane jest przez zwykłą, opisową referencyjność, która kieruje naszą uwagę na przedmioty „codziennej rzeczywistości i nauki” (Ricœur 2011: 68). Tyle Ricoeur, którego uwagi o „objawieniowym” wymiarze poezji pozwalają lepiej zrozumieć maksymalistyczne intencje Barańczaka.

Powróćmy teraz do komentowanego wiersza i zapytajmy, dlaczego Barańczak podejmuje dialog z Dickinson? Najprostsza odpowiedź brzmi: bo szuka u niej pomocy. Wspomniane powyżej nawiasowe wzmianki z Tablicy $z$ Macondo, a przede wszystkim te fragmenty poematu, które są ,pocztówkami do Emily Dickinson", mogą sugerować, że potrzebuje jej, by odzyskać pewność co do realności trzech punktów odniesienia - Innych, Świata i Transcendencji. On sam jest poetą drugiej połowy XX wieku, który czuje się bezradny wobec naporu zwątpienia (por. Barańczak 1996b). Ma nadzieję, że to ona nauczy go wiarygodnie i performatywnie skutecznie wypowiadać zaklęcie „ON JEST”, które ma potrójnego adresata.

Wybór Dickinson nie jest przypadkowy. Wynika z rozpoznania literackiej rangi (czyli gwarancji, że chodzi o „naprawdę dobre wiersze”4), pokrewieństwa poetyckiego idiomu (m.in. zamierzone zaburzenia składni, rytmu i rymu, unikanie brzmieniowej i stylistycznej gładkości, potoczność języka,

${ }^{4}$ Swoje wprowadzenie do 100 wierszy E. Dickinson Barańczak pointował efektownym nawiązaniem do jej wiersza o incipicie Mieszkam w pałacu możliwości: ,Jedynie ciasny pokoik strofy ma - ze wszystkich ludzkich siedzib - nadprzyrodzoną zdolność przeistaczania się w rozległy «pałac Możliwości»" (Barańczak 1990: 22). To zdanie jest w istocie hołdem złożonym ,nadprzyrodzonemu” talentowi poetki. 
skłonność do przerzutni, kondensacja znaczeń, wreszcie skupienie na obrazowym konkrecie), ale też bliskości geograficznej, bo Barańczak zamieszkał pod Bostonem, skąd blisko było do Amherst, gdzie sto lat wcześniej poetka wiodła swe samotnicze życie. Mam wrażenie, że to właśnie nieoczekiwane zanurzenie w tym samym krajobrazie ośmieliło Barańczaka do dialogu, który przybiera formę osobistej Ars poetica ${ }^{5}$. Dialog w poemacie dotyczy rozumienia istoty poezji, a także jej performatywnej, czy nawet „nadprzyrodzonej" mocy, która obiecuje tryumf nad przemijaniem.

Pięć pocztówek od i do Emily Dickinson utkanych jest z licznych aluzji, nawiązań do jej konkretnych wierszy. Chyba najważniejsze utwory, które służą jako programotwórcze punkty odniesienia, to wspomniany już Bywa światta pochylenie (w oryginale incipit: There is a Certain Slant of Light), This is my Letter to the World (w przekładzie Barańczaka: To wszystko - to mój list do świata), The Soul Selects her own Society (w przekładzie Barańczaka: Dusza dobiera sobie towarzystwo) oraz The Missing All-Prevented Me (w przekładzie Barańczaka: Skoro nie mogłam mieć Wszystkiego) ${ }^{6}$. Nie zdołam w tym miejscu oddać sprawiedliwości kunsztowi Barańczaka, który nie tylko nawiązuje do konkretnych wierszy Dickinson, ale także naśladuje rwany rytm jej składni, znajduje metryczne odpowiedniki dla jej nieregularnego jambu. Co znamienne zresztą, imitacja zauważalna jest nie tylko w pocztówkach od, lecz także do. W moich zdawkowych komentarzach skupię się na ewokowanych przez pocztówki dwóch programach poezji, a wreszcie próbuję odpowiedzieć na pytanie najważniejsze - jak rozumieć zamysł pastiszu wpisany w Pięć pocztówek od i do Emily Dickinson. Czy ma on coś wspólnego z maksymalistycznymi celami, które Barańczak stawiał przed poezją w swoich manifestach?

Zacznijmy od programów. Najprościej rzecz ujmując, pocztówki od Dickinson mówią o poezji jako ,pałacu Możliwości”, otwarciu na „nieobjętość” i „niepojętność całą”, czyli niezgodzie na zawężenie do czasu i miejsca, które wyznaczyły ramy jej egzystencji. Z niezgody tej wynika niechęć do poezji rozumianej jako produkcja „oleodruków sumienia”. Ta metafora odnosi się do jakiejś tandetnej podróbki prawdziwego obrazu świata, która jest jedynie ekspresją słusznego buntu, protestu, ale nosi piętno

5 Tak postrzegają ten wiersz Kandziora (Kandziora 2007) i Rabizo-Birek (Rabizo-Birek 1994). Ciekawe byłoby zestawienie Pięciu pocztówek... z Nie więcej Miłosza i Dlaczego klasycy Herberta.

6 Spośród innych wierszy pośrednio przywoływanych w poemacie warto wymienić te, które mówią o skandalu śmierci - I've seen a Dying Eye, A Coffin is a small Domain. 
schematyzmu i doraźności. Świat Dickinson jest substancjalny, mieści w sobie czerwień zachodzącego słońca i ślimaka na ścieżce. Poetka odsłania go, mając poczucie, że Ktoś ukryty, Transcendencja, nadaje mu bezwzględny sens. Pocztówki od Barańczaka (tak nazwijmy umownie podmiot liryczny, który dialoguje z Dickinson) są wyznaniem na temat niemocy własnej poezji i podrzędności roli producenta „oleodruków sumienia”. Miarą tej poezji jest gest moralny, protest ręki, która „nie umiała / podpisać aktu zdrady” (Barańczak 2013: 312) . To za mało, by oprzeć się potędze Nicości. Przypomnijmy, że Nicość - pojęcie, którym Barańczak posługiwał się w swoich manifestach - ma w jego ujęciu co najmniej dwa znaczenia: śmiertelności ludzkiego świata, ale i tryumfu historycznego zła.

Rozmowa między mówiącymi w wierszu podmiotami - „Barańczakiem” i „Dickinson” - dotyczy sposobów przeciwstawiania się, unieważniania Nicości. „Barańczak” widzi swą poezję jako bezradny i właściwie żałosny gest protestu, „Dickinson” jako próbę ocalenia świata. Ich dialog jest tak skonstruowany, by wskazać na wspólnotę przestrzeni i doświadczenia, lecz zaznaczyć odmienność perspektyw. Oboje dostrzegają w świecie trywialność i zbrodnię (zaskakujące niedokładne zrymowanie „trotuar z kredowym obrysem” z „tortura”), oboje doznali bezsilności wobec śmierci bliskich. A jednak „Dickinson” umyka Nicości.

Na tryumf „Dickinson” może wskazywać ostatnia pocztówka, choć na początku eliptycznego zdania pojawia się tryb warunkowy („Jeśli świat się w nim rozpozna”). O skuteczności jej strategii unieważniania Nicości zadecyduje coś, o czym wspomnimy za chwilę. Tymczasem przyjrzyjmy się bliżej pierwszej strofie:

Jeśli świat się w nim rozpozna,

słowo - w końcu - jest tym

światem - jest gdzieś ponad - poza

zgodą czy protestem - (Barańczak 2013: 313)

Pojawia się tu kilka znamiennych sformułowań. Co znaczy, że słowo to „świat” i że jest gdzieś „ponad”, ,poza/ zgodą czy protestem”? Chodzi chyba o to, co można nazwać za Ricoeurem „objawieniowym” wymiarem języka poetyckiego, o odsłanianie pierwotnego zakorzenienia. Ale tryb warunkowy wprowadza dodatkowy aspekt - słowo staje się światem, jeśli świat się w nim rozpozna. „Dickinson” akcentuje wymiar koniecznościowy poetyckiego słowa, to, co Barańczak nazywał w swym manifeście: „tak-a-nie-inność”. Ta radykalna nieprzypadkowość słowa, jego skuteczna 
referencyjność jest ostatecznie oparta na religijnym przekonaniu czy, mówiąc językiem Newmana, realnym (nie pojęciowym) przyświadczeniu ${ }^{7}-\dot{z} e$ „ON JEST”. To dlatego „, tak warto/ocalić” świat „z każdą usterką - / do krwi - w całym blasku śniegu" (Barańczak 2013: 314). W tym ostatnim wersie zwróćmy uwagę na frazę „w całym blasku śniegu”, która domyka grę z wierszem Bywa światła pochylenie (zainicjowaną w pierwszej pocztówce), ale i wprowadza aluzję do ważnego motywu poezji Barańczaka - śniegu jako ambiwalentnego (niszczącego lub oczyszczającego) znaku sacrum (Kandziora 2007: 155).

Powróćmy teraz do zadanego wcześniej pytania: jak rozumieć zamysł pastiszu wpisany w Pięć pocztówek od i do Emily Dickinson? Otóż pastisz jest w tym wypadku konstrukcją nadzwyczaj przemyślną i najzupełniej poważną. Stanisław Barańczak, podmiot czynności twórczych, kreuje głosy dwojga lirycznych podmiotów, „Emily Dickinson” i „Stanisława Barańczaka”, którzy toczą z sobą fikcyjny dialog, ale nie chodzi mu jedynie o warsztatową wprawkę. Autor chce sprawdzić, czy potrafi w trybie imitacji stworzyć słowa-światy, które zyskają „,nadprzyrodzoną” moc oryginału Dickinson. Imitacja oznacza w tym wypadku coś więcej niż sprostanie wymogowi „naprawdę dobrego wiersza”. Wiąże się z egzystencjalnym pragnieniem, by realnie przyświadczyć „ON JEST”, by na powrót zaczarować świat. Barańczak imituje, ale jako czytelnik Dickinson i poeta tworzący Pięć pocztówek od $i$ do Emily Dickinson realnie przyświadcza, że świat „w całym blasku śniegu” opiera się Nicości. Także my, jego czytelnicy, poddajemy się jego gramatyce przyświadczenia ${ }^{8}$.

7 Przypomnijmy, że w Logice wiary Newman wskazywał na różnicę między prawdą zdania (jego koherencją, oczywistością) a jej uznaniem (,przyświadczeniem”) przez konkretnego człowieka. Badając różne stopnie ,przyświadczenia”, wyróżnił przyświadczenie pojęciowe i realne. To pierwsze przybiera formę hipotezy, poglądu, deklaracji itp., ale nie ma mocy sprawiającej, że do wypowiadanej prawdy ,przylegamy” i w oparciu o nią działamy. Dopiero przyświadczenie realne, nazwane ,aktem intelektualnym, którego przedmiot przedstawia wyobraźnia” (Newman 1989: 85), powoduje, że pewna asercja staje się prawdą w horyzoncie egzystencjalnym. Por. na ten temat artykuł Jana Kłosa (Kłos 2012).

${ }^{8}$ Formułę gramatyki przyświadczenia zastosował w badaniu związków literatury i religii David Jasper (2016). Por. także wywiad (Jasper 2020). 


\section{Bibliografia}

Barańczak S. 1990. Wstęp, w: E. Dickinson, 100 wierszy, wybór, wstęp i przekład S. Barańczak, Kraków: Arka, s. 5-22.

- 1993. Poezja musi być wieczna czujnością. Ze S. Barańczakiem rozmawia P. Wierzchosławski, w: K. Biedrzycki (red.), Zaufać nieufności. Osiem rozmów o sensie poezji, Kraków: Wydawnictwo m, s. 59-79.

- 1996a. Tablica z Macondo, w: S. Barańczak, Poezja i duch uogólnienia, Kraków: Znak.

- 1996b. Zemsta ręki śmiertelnej, w: S. Barańczak, Poezja i duch uogólnienia, Kraków: Znak.

- 2013, Wiersze zebrane, Kraków: a5.

Jasper D. 2016, Literature and Theology as a Grammar of Assent, Farnham: Ashgate.

- 2020, Osłabianie teologii przez literature: David Jasper odpowiada na pytania Tomasza Garbola i Łukasza Tischnera, w: Ł. Tischner, T. Garbol (red.), Literatura a religia: wyzwania epoki świeckiej, t. 1: Teorie i metody, Kraków: Wydawnictwo Uniwersytetu Jagiellońskiego, s. 787-814.

Kaczorowska M. 2011, Przekład jako kontynuacja twórczości własnej. Na przykładzie wybranych translacji Stanisława Barańczaka z języka angielskiego, Kraków: Universitas.

Kandziora J. 2007, Ocalony w gmachu wiersza. O poezji Stanisława Barańczaka, Warszawa: IBL.

Kłos J. 2012, Pewność zdania a pewność osoby - czyli o strukturze przyświadczenia, „Przegląd Filozoficzny”, cz. I, R. 21, nr 2(82), s. 73-86.

Newman J.H. 1989, Logika wiary, przeł. P. Boharczyk, Warszawa: Instytut Wydawniczy Pax.

Rabizo-Birek M. 1994, Traktat poetycki Stanisława Barańczaka. Stanisław Barańczak -,,Pięć pocztówek od i do Emily Dickinson”, w: P. Żbikowski (red.), Wśród starych $i$ nowych lektur szkolnych - zbiór analiz i interpretacji, Rzeszów: Wydawnictwo Wyższej Szkoły Pedagogicznej, s. 211-228.

Rajewska E. 2007, Stanisław Barańczak - poeta i tłumacz, Poznań: Wydawnictwo Poznańskie.

Ricoeur P. 2011, Pomiędzy filozofia a teologia: nazywanie Boga, thum. R. Grzywacz SJ, w: P. Ricoeur, Nazwać Boga, Kraków: WAM, s. 61-84.

Taylor Ch. 2007, A Secular Age, Cambridge, MA: Belknap Press of Harvard University Press.

Tischner Ł. 2020, Epifaniczna moc literatury: o badaniach Charlesa Taylora, w: Ł. Tischner, T. Garbol (red.), Literatura a religia: wyzwania epoki świeckiej, t. 1: Teorie i metody, Kraków: Wydawnictwo Uniwersytetu Jagiellońskiego, s. 19-55. 